\title{
The Case for Coase and Against "Coaseanism"
}

\author{
Robert C. Ellickson†
}

Poor Ronald Coase. In an introductory essay to a recently published collection of his articles, Coase laments his lack of influence among economists. "My point of view has not in general commanded assent, nor has my argument, for the most part, been understood."1 One can imagine the muttering that Coase's plaint will provoke in the university towns across America. "Wait a minute, buster," will grouse the professors. "It must be tough when you've merely written the most cited article in the legal literature $^{2}$ and when Yale has been bothering you with the offer of an honorary degree. Listen up and we'll tell you some stories about scholarship that has gone underappreciated."

But wait! After reading John Donohue's stimulating and useful contribution to this issue, ${ }^{3}$ one can see that Coase indeed deserves some sympathy. In Donohue's article, which in this regard is representative of lawand-economics writing in general, Coase's name is consistently attached to propositions that he has explicitly repudiated. ${ }^{4}$ Predictions identified as "Coasean" are predictions that Coase would never make. The "Coasean world" is not only not Coase's world but, ironically, is more like the world of the economic theorists that Coase has attacked. The "Coasean River" in Donohue's title is not one that Coase believes has ever flowed.

† Walter E. Meyer Professor of Property and Urban Law, Yale Law School. I thank Henry Hansmann and Alan Schwartz for their help.

1. R. Coase, The Firm, the Market, and the LAw 1 (1988).

2. Fred Shapiro identified Gunther, The Supreme Court, 1971 Term-Foreword: In Search of Evolving Doctrine on a Changing Court: A Model for a Newer Equal Protection, 86 HARv. L. REv. 1 (1972), as the article appearing in a conventional law review between 1947 and 1985 that was the most cited in conventional law reviews during the 1957-1985 period. Shapiro, The Most-Cited Law Review Articles, 73 Calif. L. Rev. 1540, 1549 (1985). Shapiro stressed that his study did not count citations to oft-cited articles published in interdisciplinary journals. He identified Coase's The Problem of Sacial Cost as the "most notable example" of such an article. Id. at 1546. INSTITUTE FOR ScIentific Information, InC., Social. ScienCe Crtation Index, provides a basis for counting all citations made in major periodicals in law, economics, and other social sciences. According to this Index, Coase's Social Cost received an average of 91 citations per year during 1981-1985 and 92 per year during 1986-1988. These numbers are nearly twice the numbers the same Index reports for the Gunther Foreword, which averaged 55 citations per year during 1981-1985 and 48 per year during 1986-1988.

3. Donohue, Diverting the Coasean River: Incentive Schemes to Reduce Unemployment Spells, 99 YALE L.J. 549 (1989) [hereinafter cited by page number only].

4. Although Donohue succumbs to the widespread practice of misusing the adjective "Coasean," he is aware of Coase's real views. See p.549 n.2. 
Just as some believe Marx would complain of what is currently done in the name of Marxism, Coase has reason to be appalled at the emerging contours of "Coaseanism."

I will set forth some basic propositions of law-and-economics that are different from, and more promising than, the "efficiency," "invariance," and "distributional" predictions that Donohue labels "Coasean." My propositions are not only more consistent with Coase's actual beliefs about the world but, more pertinently, also constitute a better foundation for work in law-and-economics. ${ }^{6}$ In offering this alternative, I do not intend to slight Donohue's substantial accomplishments. He deserves particular credit for recognizing that a treasure was hidden within Woodbury and Spiegelman's grand experiment with $\$ 500$ bonus payments to reward the speedy reemployment of Illinois workers who had been collecting unemployment insurance benefits. Because one branch of the Illinois experiment offered bonuses to workers and another branch offered bonuses to employers, Donohue saw that Woodbury and Spiegelman's results would provide a prism on the assumptions underlying the Coase Theorem. Although I will stress my differences with Donohue, he and I agree on many points, particularly on the proposition that in most instances the world is full of transaction costs.

\section{The Cardboard Coase and the Real Coase}

The essence of Coase's argument, which he first developed in his twenties in The Nature of the Firm, ${ }^{7}$ is that transaction costs are large and that economic actors tend to arrange their institutions with an eye to these costs. ${ }^{8}$ Although much of Coase's later and more cited article, The Problem of Social Cost, ${ }^{9}$ did discuss at great length the operation of a fanciful world of zero transaction costs, even in that work Coase took pains to stress that transaction costs exist and must be taken into account. ${ }^{10}$ In a retrospective essay in his recent book, Coase writes: "The world of zero

5. Coase might take some solace in the fact that his own notion of transaction costs may help explain why he has been victimized in this way. Theorists with one syllable names are the ones most likely to find their names converted into adjectives.

6. Coase uses the rational-actor model of human behavior that is standard in economics. Coase nevertheless has asserted that this model is overly simple. See R. CoASE, supra note 1, at 3-5. A richer law-and-economics would take more explicit account of cognitive limitations, the psychological disposition to value a thing in hand more than a prospect, and the influence of internalized norms. See A. Etzioni, The Moral Dimension: Toward a New Economics (1988); Ellickson, Bringing Culture and Human Frailty to Rational Actors, 64 CHI.-KENT L. REV. 23 (1989); Knetsch, The Endowment Effect and Evidence of Non-Reversible Indifference Curves, 79 AM. ECON. REv. (forthcoming 1989). Donohue, it should be noted, is commendably attentive to the psychology of bargaining. See pp. 601-04.

7. 4 ECONOMICA 386 (1937), reprinted in R. COASE, supra note 1, at 33-55.

8. Coase did not actually employ the phrases "transaction costs" and "Coase Theorem" in his pioneering articles.

9. 3 J.L. \& ECON. 1 (1960), reprinted in R. COASE, supra note 1, at 95-156.

10. R. COASE, supra note 1 , at 114-19. 
transaction costs has often been described as a Coasian ${ }^{11}$ world. Nothing could be further from the truth. It is the world of modern economic theory, one which I was hoping to persuade economists to leave."12

All three of Donohue's asserted "Coasean predictions"13 flow from the figment that transaction costs are zero. More in tune with Coase's actual beliefs are two basic propositions, from the second of which follow two narrower propositions:

(1) "there are transaction costs and . . . they are large;"14

(2) people tend to arrange their affairs so as to minimize the sum of their (a) transaction costs and (b) deadweight losses arising from their failures to exploit gains from trade; ${ }^{15}$

(3) in situations where law actually governs entitlements, the conferral of a legal entitlement may affect the allocation of resources (that is, have flypaper effects) when the transaction costs of transferring the entitlement to a person who values it more highly would exceed the gains from that trade, ${ }^{16}$ and

(4) a rational actor, peering unconfidently through the fog that separates ordinary people from legal rules and institutions, will ignore how the legal system sets entitlements when he calculates that his expected costs of learning and enforcing his legal entitlements would exceed the expected value of those entitlements to him. ${ }^{17}$

These four propositions are not as quantifiable, and hence as falsifiable, as the claims that Donohue associates with the Coase Theorem. To test this alternative set of positive propositions, economic theorists would need to add transaction costs to their equations and embark on the grubby (but essential) business of trying to monetize transaction costs in actual settings. This work is likely to be more difficult and less elegant than armchair theorizing about whether strategic behavior, or wealth effects, or nonconvexities, or what-not might undermine Coase-Theorem predictions about life in the never-never-world of zero transaction costs. Transaction costs themselves thus help explain why there has been little empirical work on transaction costs. ${ }^{18}$

11. On the fiercely debated issue of whether the preferred spelling is "Coasean" or "Coasian," the detinitive analysis is Schwab, A Coasean Experiment on Contract Presumptions, 17 J. LEGal STUD. $237,237 \mathrm{n} *$ (1988).

12. R CoAse, supra note 1 , at 174 (footnote added).

13. P. 554

14. R. CoAsE, sufra note 1 , at 26 .

15. This is the implicit theme of The Nature of the Firm, supra note 7.

16. $\mathrm{R}$ CoAsE, supra note 1 , at $115,133,175-76$.

17. I stress this poin, which is not found in Coase, in R. Ellickson, ORder Without LAw (forthcoming 1991), and in Ellickson, Of Coase and Cattle: Dispute Resolution Among Neighbors in Shasta Caunty, 38 STAN. L. REV. 623 (1986) [hereinafter Shasta Caunty]. The costs of pursuing one's legal rights may include not only the costs of legal information and involvement in the legal systum, but also the costs of bearing the informal punishments that members of many societies impose on persons who are overly legalistic.

18. Coase himself may deserve a bit of blame for the interminable analysis of the zero- 


\section{II. "TRANSACTION COSTS . . ARE LARGE"19}

Coase himself has said it. Field evidence shows it. ${ }^{20}$ Law-and-economics scholars should heed it.

In his analysis of the Illinois experiment, Donohue does not give transaction costs their due. He starts with the assumption, which he later qualifies, that transaction costs were "relatively low" in the Illinois experiment. ${ }^{21} \mathrm{He}$ sees the experimental conditions as enabling a worker and employer, two parties already negotiating with each other in an atmosphere free of the perils of bilateral monopoly, to execute a simple bargain splitting the state's $\$ 500$ bonus between them. For three reasons, developed below, this view underestimates the transactional frictions that were present. First, three parties had to cooperate in two different transactions over the space of several months before the state would send a bonus check. Second, the vast majority of Illinois employers were organizations, not individuals; it is inherently more costly for an organization than for an individual to enter into an unfamiliar contractual arrangement. Third, and more generally, because transaction costs are so hydra-headed, one can infer little from a showing that some of these costs are low.

\section{A. A Taxonomy of Transaction Costs}

Law-and-economics has suffered from the absence of an accepted vocabulary for disaggregating the general notion of transaction costs. A tidy categorization is probably not possible. Nevertheless, it is useful to divide transaction costs along two dimensions.

The first dimension, which scholars have previously explored, ${ }^{22}$ is

transaction-costs world. Although his writings often emphasize the value of studying real situations, he has published but one major empirical study, The Lighthouse in Economics, 17 J.L. \& Econ. 357 (1974), reprinted in R. Coase, supra note 1, at 187-213. Coase's recent essay, Notes on the Problem of Social Cost, in R. COASE, supra note 1, at 157-85, for the most part is a response to others' critiques of his analysis of the dynamics of a world without transaction costs. Id. at 157-74. He devotes less space to exploring the implications of the fact that transaction costs exist. See id. at $174-85$.

19. R. COASE, supra note 1 , at 26 .

20. See, e.g., sources cited infra notes $80-82$.

21. P. 556. Other talented law-and-economics scholars have similarly succumbed to the temptation to downplay transactional frictions. See Hoffman \& Spitzer, Experimental Tests of the Coase Theorem with Large Bargaining Groups, 15 J. LEGAL SruD. 149, 151, 171 (1986) (expressing excessive optimism about real-world implications of results of highly artificial laboratory experiment); Vogel, The Coase Theorem and California Animal Trespass Law, 16 J. LEGAL STUD. 149, 161 (1987) (suggesting, contrary to evidence presented in Shasta County, supra note 17, that formal legal bargaining between neighboring farmers and ranchers could take place under conditions of low transaction costs).

22. Coase himself appears to emphasize this dimension. He has endorsed Dahlman's tripartite division of transaction costs into "search and information costs, bargaining and decision costs, . . . [and] policing and enforcement costs." R. Coase, supra note 1, at 6 (citing Dahlman, The Problem of Externality, 22 J.L. \& ECoN. 141, 148 (1979)); see also O. Williamison, The Economic Institutions of Capitalism: Firms, Markets, Relational Contracting 20-22 (1985) (distinguishing between ex ante and ex post transaction costs). 
chronological. It classifies a cost according to whether it was incurred at a pre-bargain, bargain, or post-bargain stage.

The second dimension, which I will emphasize in my analysis of the Illinois experiment, is functional. It looks to the type of impediment that the person who incurred the cost was seeking to overcome. As an initial cut, transaction costs can be divided into three somewhat overlapping functional categories: ${ }^{23}$

(1) get-together costs,

(2) decision and execution costs, and

(3) information costs.

Get-together costs are the burdens of arranging physical and electronic connections among transacting parties. They include the costs of establishing lines of communication, setting up meetings, and transporting parties and goods.

Decision and execution costs are the costs, apart from information costs, that parties who have gotten together incur to actualize their agreement. Decision costs are in evidence when an individual wants to "mull over" an opportunity to trade (or to receive a government grant). In many contexts, such as ordering at a restaurant, an individual's decision costs are likely to be trivial. Decision costs are likely to be nontrivial, however, when a transacting party is either a nonhierarchical group of two or more persons who must coordinate together or a hierarchical organization with a multi-person decisionmaking structure. Execution costs include the costs of documenting a deal. ${ }^{24}$

Information costs, the broadest of the three functional categories, warrant further subdivision. When an item is available through trade or through a government grant program, a person who might acquire the item would benefit from factual information of four sorts:

(a) information on the item's quality (the attributes that a full owner of the item would enjoy),

(b) information on the item's title (that is, on the existence of third-party claims that might limit the transferor's capacity to pass full ownership of the item),

(c) information on the price and terms that the transferor will ultimately charge, and

(d) information about the transferor that would help the acquirer predict the transferor's behavior in subsequent dealings.

Factual information of these sorts is obtained through inspection, research,

23. The purpose of the taxonomy is to provide an exhaustive checklist of transaction costs. Given that aim, overlaps are less worrisome than omissions.

24. The formalization of an oral deal involves analogous costs. 
and bargaining. ${ }^{25}$ To appraise the significance of this factual information, a potential transferee would also benefit from having legal information about the rules of entitlement that an adjudicator would apply to decide a post-bargain dispute. ${ }^{26} \mathrm{~A}$ person considering buying a house, for example, might hire a carpenter and a title company to investigate respectively for quality and title defects in the house; to judge the significance of defects that these fact-finders turn up, the homebuyer might hire an attorney.

When alternative sources of an item exist, as they usually do, a wouldbe acquirer may go through a process of search. A searcher arranges gettogethers with, and makes factual inquiries of, a number of potential trading partners. ${ }^{27}$ By generating information about alternative opportunities, the search process helps a searcher decide on the price and terms of his offers to a particular transferor.

Too many scholars have leapt from the observation that some sorts of transaction costs are low to the conclusion that aggregate transaction costs are low. ${ }^{28}$ This is rash. In the Illinois experiment, particularly in the employer-payment-group (EPG) experiment, aggregate transaction costs cannot be characterized as low.

\section{B. Multiple Transactions Were Necessary}

Before the state would agree to pay a $\$ 500$ bonus in the Illinois experiment, two transactions had to be completed. One transaction was that between the recipient of the bonus check and the state Department of Employment Security. Under both the EPG and WPG (worker-paymentgroup) programs, the government-benefit transaction could not be consummated unless three parties (worker, employer, state) each acted cooperatively on two occasions some four months apart. ${ }^{29}$

The other transaction was a contract of employment between worker and employer. When negotiating this contract, to figure in the possibility

25. Strategic behavior by a bargainer is designed to generate information about a transferor's reservation price and terms.

26. When a legal system is committed to enforcing contract provisions, the parties themselves can make many of the applicable legal rules. Express warranties, for example, can govern a transferor's obligations of quality or title. The negotiation of these sorts of clauses can therefore serve to reduce the parties' costs of obtaining legal information. On the other hand, the process of creating these clauses is itself likely to give rise to additional get-together, decision, and execution costs.

27. A searcher who stayed within a single legal jurisdiction, however, would have to conduct only a single legal inquiry if all the transactions under consideration would pose identical doctrinal issues.

28. See, e.g., sources cited supra note 21.

29. The instructions called for both worker and employer to sign both the Notice of Hire form and also, four months later, the Voucher form. See infra text accompanying note 49. Participants mailed completed forms to the Department for review and approval.

The state ended up not making the filing of a Notice of Hire a condition of bonus receipt. $S$. Woodbury \& R. Spiegelman, Bonus-Payment Errors and Take-Up Rates in the Illinois Experiments: Reply 2 (Nov. 1988) (unpublished manuscript on file with author). The WPG and EPG information packets, however, told would-be participants that submission of a Notice of Hire form was mandatory. See infra note 42 . These forms were in fact submitted in about $95 \%$ of the cases in which bonuses were paid. See p. 571 (Table I n.3). 
that one of them might receive a $\$ 500$ bonus payment several months later, the worker and employer would have to guess at the likelihood that the three-party, government-benefit transaction would later be consummated. In short, the Illinois experiment was not transactionally simple; a worker-employer deal to split a bonus would require more get-togethers and decisions than a single-shot, two-party transaction typically does.

\section{G. Organizations May Not Be Able To Exploit Unexpected Contracting Opportunities Cheaply}

Donohue devotes only a sentence or two to the implications of the fact that the Illinois workers involved in the experiment mostly sought job offers from large organizations. ${ }^{30}$ Organizations cannot nimbly respond to unusual business opportunities. Their decision costs are certainly not low when, as in the case of both the EPG and WPG experiments, the business opportunity falls into the lap of a member of middle management.

Why might over one-third of EPG workers have declined even to enroll as participants? These workers may have been able to anticipate the risk of having the following sort of conversation at the end of a job interview: ${ }^{31}$

Personnel Officer: Ms. Miller, I'm going to put your application in with this batch of others we've received. Wendy Loman, my boss, told me she was going to look at the applications after lunch. You'd be surprised how popular these data input clerk jobs are. She'll call you within a day or two if the news is good. If I were you, I'd just take it easy this afternoon. Maybe go to Wrigley. The Cardinals are in town. I hate 'em, the Cardinals.

Job Applicant: $\mathrm{Er}$. . . Um . . . One final thing, since you've got a lot of applications. You might want to know that there could be $\$ 500$ in it for you if I get the job.

PO: How's that again?

$J$ A: $\$ 500$.

$P O$ : For $m e$ ? Whaddiya talkin' about? I can't take money from you. They'd fire me for that.

30. P. 591. Almost one-half of the workers involved in the three Illinois experimental groups were ricmployed by firms employing over 150 persons. Less than one-fifth signed on with firms employing 10 or fewer. R. Spiegelman \& S. Woodbury, The Illinois Unemployment Insurance Incentive Experiments Final Report, Table 6-22 (Feb. 1987) (unpublished manuscript on file with author) (hereinafter Final Report].

31. The packet of instructions for EPG participants included advice on how job applicants might converse with employers:

This is an example of what you might say:

"Hello. My name is I would like to apply for a job here. Besides being an experienced worker, I am also in a special experiment run by the State of Illinois. The State is offering to pay $\$ 500$ to the employer who hires me. This letter explains how it works."

R Spiegelman \& S. Woodbury, Final Report, supra note 30, app. A3 (HIE Instruction Form). Note that the author of the quoted passage tried, with limited success, to avoid the implication that participarits in the program were damaged goods. 
$J A$ : No, no. For your company. I think. It's all explained in this letter they want me to give you. Here's one. You can keep it. I've got a bunch of copies.

PO: [Examining letter.] What is this? From the Department of Employment Security? It says here you've been "receiving unemployment benefits."32 Fired from your last job, eh?

$J A$ : Right. Laid off.

PO: Laid off. Right. I've never seen one of these before. You must be some, uh, special sort of person to have gotten one. It's kinda complicated . . . form to mail in . . . voucher form to be mailed back ... wait four months . . questions about eligibility . . . . You serious about this?

$J A$ : Well, $\$ 500$ is nothing to sneeze at. You might even be able to afford to give a bigger paycheck to someone who could bring it in. Just joking!

PO: I hope you're joking. It'd probably cost our finance department $\$ 500$ just to figure out how to cash the check and pay the taxes and stuff. No. As I said earlier, we're talking about a Grade 5 job here. $\$ 7.30$ an hour. After six months, eligible for promotion to Grade 6. But, hey, if you'd like, I can put this letter in your file so Wendy'll see it. I won't be around to try to explain it to her this afternoon, though. I'm taking a half-day off, going to Wrigley. Whitey Herzog. I love to razz him.

$J A$ : Look, let's forget about this $\$ 500$ business. The Governor's got so many lamebrain ideas. Have fun at the game. Ozzie Smith. Let's hope he boots a few.

A large firm has inherent difficulty monitoring its employees, including staff members who are involved in the hiring of new workers. ${ }^{33}$ To limit staff discretion, a firm is likely to set bureaucratically the wages and benefits that attach to lower-tier jobs. ${ }^{34} \mathrm{~A}$ firm's policies and practices would be unlikely to allow these hirings to be occasions for fine-tuned bargaining over compensation. ${ }^{35}$

A related point is that it would be unusual for a middle-managernent personnel officer to encounter a surprise opportunity to raise revenue for the firm. As a result, a personnel officer might even react negatively to an

32. The letter to employers began: "This will introduce [name of applicant] who is steking employment and receiving unemployment benefits under the Illinois law. He/she has been selected for an experiment designed to encourage the speedier reemployment of unemployed workers and to reduce outlays for benefits." R. Spiegelman \& S. Woodbury, Final Report, supra note 30, app. A3 (HIE Letter Form).

33. Monitoring costs may also explain why over a third of qualified EPG employers lost the $\$ 500$ bonus simply because their staffs failed to submit the final voucher form. See p. 574 (Table II).

34. Donohue recognizes this. P. 591.

35. I thus do not agree that it is "difficult to think of another real-world example in which bargaining costs would be as low as in this case." P. 591. 
EPG worker who came towing a mysterious, contingent claim to $\$ 500$. To collect the $\$ 500$ for the firm, the staff member would likely have to explain the state program to a number of superiors and other co-workers and also arrange for subsequent completion of the EPG-bonus paperwork. ${ }^{36}$ What personal benefit could the staff member expect to derive from this work? The firm's executives would be unlikely to regard pursuit of a contingent claim to $\$ 500$ as a great feat, especially in light of the transaction costs of its collection. Moreover, a worker's membership in the EPG implied to many that he was a risky hire. ${ }^{37} \mathrm{~A}$ personnel officer might expect to be judged by superiors mainly according to the criteria of job performance that traditionally apply to personnel work. According to these criteria, the officer's role is to hire quality workers, not to raise petty revenue. A risk-averse personnel officer therefore might well decide not to pursue an EPG bonus.

The experimenters forecasted that only ten percent of EPG workers would decline to participate. It turned out, however, that about sixty percent of EPG workers who met the reemployment conditions never bothered to mention the program to prospective employers. ${ }^{38}$ The Department ended up spending on average only $\$ 14$ in bonus money per EPG worker. ${ }^{39}$ Although other credible hypotheses can be advanced for these results, one possible interpretation is that most EPG workers were able to anticipate the bureaucratic realities of employer decision-making.

\section{That Some Categories of Transaction Costs Are Low Does Not Imply that "Coasean" Bargaining Conditions Exist}

Gertain transaction costs were undoubtedly low in the Illinois setting. Get-togethers between workers and employers were destined to occur even in the absence of the experiment. A bonus recipient could easily judge the quality attributes and price of what the state was offering. The Department was tendering $\$ 500$ at a price of $\$ 0$. (A potential acquirer of money rarely needs factual information about product quality.) Because the $\$ 500$ bonus was an unusual windfall not available through markets, program participants were unlikely to search for alternatives. Finally, as Donohue explains, ${ }^{40}$ bargaining processes in this instance were unlikely to be plagued by strategic behavior.

For the conditions of the Coase Theorem to be satisfied, however, it is

36. Spiegelman and Woodbury, who designed and managed the experiment, recognized that transaction costs would keep many employers from collecting EPG bonuses. See R. Spiegelman \& S. Woodbury, Final Report, supra note 30, at 8.7 (EPG workers had to communicate program to employers, many of whom "would not want to become involved with government red tape for such a small sum of money").

37. The stigma issue is discussed more fully infra notes 51-55 and accompanying text.

38. R. Spiegelman \& S. Woodbury, Final Report, supra note 30, at 7.6 \& Table 7-6.

39. P. 571 (Table I).

40. Pp. $555-58$. 
not enough that some varieties of transaction costs are low. That bargainers are able to get together in an atmosphere of cooperation does not, for example, imply that they have the factual and legal information they need to appraise their own and others' assets. Wheeler-dealers cannot trade what they don't know they have.

To garner a bonus, participants in the Illinois programs had to acquire costly information. To assess the value of a contingent claim for $\$ 500$ against the state Department of Employment Security, participants first had to master a set of unfamiliar documents that identified the program terms. ${ }^{41}$ The entitlement to $\$ 500$ was contingent on the workers', employers', and state officials' future satisfaction of five potentially burdensome conditions. ${ }^{42}$ The most daunting of these were that the unemployed worker find a thirty-hour-a-week or greater job within eleven weeks (after what starting point, diligent reader?) and then hold that job for four months. These job conditions proved to be onerous; less than a quarter of the unemployed workers in all experimental groups ended up meeting them.

Participants also faced the burden of gathering facts relevant to the appraisal of the magnitude of the real risks that the five formal conditions posed. In particular, participants had to estimate, at time of hire, the likelihood that the employment relationship would endure for four months. This required a guess at the likelihood of future cooperative behavior on the part of the (probably unfamiliar) party on the other side of the employment contract.

There were also factual uncertainties about the competence of the Department, the transferor of the bonus. An experienced Illinois resident (for example, Ronald Coase himself) might not have total faith that promises made by Illinois agencies would be smoothly executed. A potential recipient might worry, for example, that bureaucratic bungling would lead to loss of the bonus check. A street-smart participant, wary of a deal that offered something for nothing, might imagine that the state was setting a trap. For example, a worker or employer might envision that participation in the program would trigger a tax audit or some equally unwelcome state

41. To reduce burdens on workers, specialists located in Illinois State Job Search offices were assigned the task of explaining the program face-to-face. R. Spiegelman \& S. Woodbury, Final Report, supra note 30 , at $3.8,3.9$.

42. The first paragraph of the instruction form for workers assigned to the EPG included the following:

FOR THE EMPLOYER TO RECEIVE THE \$500:

. YOU MUST BE ELIGIBLE TO RECEIVE UNEMPLOYMENT BENEFITS.

- YOU MUST START WORK BEFORE THE END OF 11 WEEKS AFTER YOU FIRST FILE FOR BENEFITS.

. THE JOB MUST BE FOR AT LEAST 30 HOURS PER WEEK.

. EMPLOYER MUST SEND NOTICE OF HIRE FORM TO DES.

. YOU MUST STAY ON THE JOB FOR AT LEAST 4 MONTHS.

R. Spiegelman \& S. Woodbury, Final Report, supra note 30, app. A3 (HIE Instruction Form). The WPG instruction form included a comparable five-point list. Id. at app. A3 (JSIE Instruction Form). 
response. Gathering the information needed to allay these sorts of fears would be costly for participants.

The employer-payment program was used much less than the workerpayment program was. Donohue correctly states that this asymmetric result is inconsistent with what the Coase Theorem predicts would happen in a zero-transaction-costs world. It is perfectly consistent, however, with what a true Goasean would predict for the real world.

The Illinois experiment was structured so that the transaction costs of employers' collecting bonuses were invariably higher than the costs of workers' collecting bonuses. Under the worker-payment program, only workers had to learn the moderately complex terms of the state's offer. Under the employer-payment program, however, both workers and employers had to learn these terms, and workers had to take the initiative in educating employers about them. ${ }^{43}$

Although WPG workers as a group participated in the program to a greater extent than the EPG workers did, many WPG workers did not steadfastly pursue the $\$ 500$ bonus check. Spiegelman and Woodbury received only $65 \%$-to- $70 \%$ of the Notices of Hire they expected from WPG workers. ${ }^{44}$ Of WPG workers who satisfied all job conditions, only $54 \%$ collected bonuses. ${ }^{45}$ Of those who had both met all job conditions and filed Notices of Hire, over one-sixth forfeited their $\$ 500$ checks by failing to arrange for the execution and mailing of the voucher after four months of employment. ${ }^{46}$

Donohue is puzzled that "a sizable number of workers . . . seem to have passed up free money." 47 worker notified of inclusion in the WPG was not, however, like a prizewinner who has been handed an envelope containing $\$ 500$ in folding money. Not only was the claim contingent, but a worker had to incur nontrivial transaction costs to collect it. In particular, employers were more involved in WPG paperwork than Donohue implies. ${ }^{48}$ The forms used in the Illinois experiments reveal that WPG workers pursuing bonuses were twice instructed to ask their employer to fill out and sign an unusual government document. A WPG worker had to obtain the signature of an employer representative both on the initial Notice of Hire and also on the Voucher, which was sent to the Depart-

43. The experimenters identified the first of these as the basic reason why the state ended up paying tewer EPG than WVG bonuses. See Woodbury \& Spiegelman, Bonuses to Workers and Employers to Reduce Unemployment: Randomized Trials in Illinois, 77 AM. ECoN. REv. 513, 516 (1987) [hereinafter Bonuses to Workers]. As they and Donohue have also pointed out, a worker who sought an EPG bonus was more stigmatized than a participating WPG worker was. See infra notes 51-55 and accompanying text.

44. R. Spiegelman \& S. Woodbury, Final Report, supra note 30 , at 3.15 .

45. Woodbury \& Spiegelman, Bonuses to Workers, supra note 43, at 525 (Table 7).

46. P 574 (Table II).

47. P. 607 .

48. Donohue states that a WPG worker could simply decline to tell an employer about the existence of the bonus. Pp. 592-93, 600. 
ment four months later. ${ }^{49}$ The task of obtaining signatures from a "boss" might be somewhat intimidating for any new employee. This step might be especially daunting for WPG workers, all of whom a few months before had gone through the demoralizing experience of being terminated from another job. ${ }^{\text {so }}$

A WPG worker, besides being concerned about needing to hassle for signatures, might fear that participation in the worker-payment program would be stigmatizing in the eyes of the employer. ${ }^{51}$ The employerpayment program, however, was unquestionably more stigmatizing than the worker-payment program was. ${ }^{52}$ The EPG letter told the employer flat out that the worker was "receiving unemployment benefits"53 and that the state was offering a $\$ 500$ reward to the employer who would put an early end to this unfortunate situation. A suspicious employer might discriminate both generally against persons "on the dole" and particularly against workers whom the state was (mysteriously) trying to bribe employers to hire. ${ }^{54}$

Although the disclosures in the worker-payment program were less blatant than those in the employer-payment program, WPG employers had notice that participating workers were up to something. A WPG worker was instructed to ask an employer representative at the time of hire to fill out and mail an unusual document, the Notice of Hire, to the Department of Income Security, the Illinois agency in charge of unemployment insurance. Although the text of this Notice did not state that the worker was

49. See R. Spiegelman \& S. Woodbury, Final Report, supra note 30, at app. A3 (JSIE Notice of Hire Form, JSIE Voucher Form).

50. The instruction letter to WPG applicants, moreover, encouraged employer involvement. It asked workers to "have your employer promptly complete the attached Notice of Hire and mail it in the enclosed self-addressed and stamped envelope." I $d$. (JSIE Letter Form).

51. To find out why so many EPG and WPG workers had declined to participate, Spiegelman and Woodbury conducted a follow-up telephone survey. Of the 151 surveyed EPG workers who had satisfied the job conditions but had never mentioned the possibility of a bonus to their employers, 11 identified "stigma" as the primary reason for their nonparticipation. R. Spiegelman \& S. Woodbury, Final Report, supra note 30, Table 7-7. Of the 21 surveyed WPG workers who remembered declining to participate, five gave stigma as the explanation. Id. at Table 7-9. Spiegelman and Woodbury, who gave more credence to these survey results than may be justified, concluded that neither stigma nor anything else stood out as the primary explanation for the low rates of participation in the two programs. See id. at ch. 7 .

Observe that workers who worry about stigmatization intuitively understand the costliness of information. Because a jobseeker should know that an employer cannot know the true attributes of a worker at the time of hire, a smart jobseeker can anticipate that an employer will be likely to rely on signals, such as a history of being on unemployment rolls, that may correlate with future worker performance.

52. See R. Spiegelman \& S. Woodbury, Final Report, supra note 30, at ch. 7, 8.6. Donohue emphasizes this point. P. 600 .

53. See supra note 32 .

54. Blacks in the EPG filed Notice of Hire forms at only one-seventh the rate that whites in the EPG did. In the WPG, by contrast, blacks filed these Notices at half the rate of whites. $R$. Spiegelman \& S. Woodbury, Final Report, supra note 30, at 7.2. One hypothesis for the startlingly low black participation in the EPG program is that black job applicants may have been more fearful than whites of being stigmatized as a result of being expressly identified as recipients of unemployment insurance. 
currently receiving unemployment benefits, the address might have prompted that inference. After completing four months on the job, a WPG worker had to obtain an employer's signature on the WPG Voucher. This Voucher, which also carried the Department's address, was likely to intrigue the employer representative asked to sign it. The function of the document was not identified. Nor was the sum of $\$ 500$ mentioned. The Voucher did, however, include a blank in which the worker was asked to indicate the address to which the "incentive payment" should be sent. ${ }^{55}$ One-sixth of eligible WPG workers passed up $\$ 500$ by neglecting to send in this form. In some instances their failure was undoubtedly caused by oversight due to the passage of many weeks. In other cases, however, an unseasoned worker might have worried that a boss would ask, before signing the Voucher, "Hey, what's this all about anyway?"

Stigma has an additional facet that economists often do not fully appreciate. One can be stigmatized in one's own eyes as well as in the eyes of another. Psychologists assert that an individual has a self-image and will make some effort to avoid dissonant events and information that would threaten maintenance of that self-concept. ${ }^{\mathbf{5 6}}$ People eligible to receive government welfare benefits may decline to apply because they do not want to think of themselves as being on the dole. ${ }^{57}$ Some Illinois workers, although willing to collect standard unemployment insurance and able to hide their WPG participation from others, might, for reasons of selfpride, have balked at pursuing the special $\$ 500$ handout. Indeed, the worker-payment program may well have threatened workers' self-concepts more than the employer-payment program did. ${ }^{58}$

\section{People Tend To Arrange Their Affairs To Minimize Their Sum of Transaction Costs and Deadweight Losses}

For Coase, this simple calculus underlies both normative and positive economics. An example of this normative perspective is his assertion that the resolution of environmental issues "is all a question of weighing up

55. R. Spiegelman \& S. Woodbury, Final Report, supra note 30, app. A3 (JSIE Voucher Form).

56. See E. Aronson, The Social Animal 85-139 (2d ed. 1976); L. Festinger, A Theory of Cognitive Dissonance (1957).

57. The Holfman and Spitzer laboratory experiments on the Coase Theorem show that internalized norms can operate to limit acquisitiveness. These scholars have often found that a subject who has been arbitrarily granted more favorable entitlements than others have will commonly share some of his good fortune with other participants. Coursey, Hoffman \& Spitzer, Fear and Loathing in the Coase Thearim: Experimental Tests Involving Physical Discomfort, 16 J. LEGAL STud. 217, 228-29 (1987); Hoffman \& Spitzer, Entitlements, Rights, and Fairness: An Experimental Examination of Subjects' Concepts of Distributive Justice, 14 J. LEGal STuD. 259, 275-80 (1985); Hoffman \& Spitzer, The Coase Theorem: Some Experimental Tests, 25 J.L. \& Econ. 73, 91-95 (1982).

58. A manager who believed that a self-respecting employer should not wallow at the government trough might similarly regard the EPG program as more offputting than the WPG program. Both conclusions assume that the participants would anticipate that the nominal recipient of a bonus check would garner most of the program benefits. 
the gains that would accrue from eliminating these harmful effects against the gains that accrue from allowing them to continue."

An important shortcoming in Coase's normative approach is that one cannot talk of "gains" and "costs" at all until a society has established some basic entitlements either informally or through its legal system. In most current societies these include an individual's rights to bodily integrity and self-ownership of labor. In the absence of such entitlements, a person who hungered for another's good would not need to trade for it but could instead simply murder or enslave the good's possessor. Until basic ground rules have been set, no prices and no markets worthy of moral respect exist. Cost-benefit analysis cannot help a society decide how to confer basic entitlements because the numbers upon which this analysis relies come into existence only after those entitlements have been conferred. $^{60}$

Nonetheless, most legal issues under current debate, such as the details of the Illinois unemployment insurance system, deal with legal minutia, not basic entitlements. When low-level legal questions are to be resolved, Coase's view that the prime normative objective should be to minimize the sum of transaction costs and deadweight losses does not trouble me. ${ }^{81}$ Whether people actually tend to pursue this utilitarian goal in their daily lives is a separate, positive question. Unlike Donohue, I construe the Illinois results as supporting Coase's view that workers and employers tend to behave as rational utilitarians. ${ }^{62}$

Although he would undoubtedly not go so far as to endorse Duncan Kennedy's assertion that "people are idiots," ${ }^{63}$ Donohue clearly has a low estimate of the savvy of workers. For example, he regards it as possible that many unemployed workers "did not understand" that an employer

59. Coase, supra note 9 , at 26.

60. See, e.g., Calabresi, About Law and Economics: A Letter to Ronald Dworkin, 8 Hofstra L. Rev. 553, 554-55 (1980); Kronman, Wealth Maximization as a Normative Principle, $9 \mathrm{~J}$. LEGAL STud. 227, 240 (1980).

61. Polinsky has lucidly argued for a presumption that distributive considerations should not influence the content of low-level legal doctrine but should instead be addressed through broad-based tax and welfare programs. See A. Polinsky, AN InTroduction to Law and Economics 105-13 (1983). The "Polinsky Theorem" is thus a fitting shorthand for the proposition that utilitarian considerations should govern choice among low-level legal rules. (This label would be even more fitting if

"Polinsky" were a name of one syllable. See supra note 5.)

62. In many policy contexts a central question is how well alternative institutions would help individuals minimize this sum of costs. Although Coase often asserts that only empirical investigation can reveal whether markets or governments are better at cost-minimization, Schwab has accurately identified an unmistakable anti-government streak in Coase's work. Schwab, Book Review, 87 MICH. L. REv. 1171, 1172 (1989) (reviewing R. CoAse, supra note 1). Coase believes, for example, that markets tend to assure that business firms are sized in a cost-minimizing way. On the other hand, presaging the current Public Choice analysis of governmental behavior, Coase has long waged a relentless war against Pigou's implicit assumption that governments (unlike markets) perform without fail. See R. COASE, supra note 1, at 20-30, 133-53, $179-85$.

63. Kennedy, Distributive and Paternalist Motives in Contract and Tort Law, with Special Reference to Compulsory Terms and Unequal Bargaining Power, 41 MD. L. REv. 563, 633 (1982) (asserting that investors in securities typically are foolish). 
might be more eager to hire someone when the state would reward the employer $\$ 500$ for exactly that deed. ${ }^{64}$

I start, as Coase does, from another premise: that people are smart. Not necessarily informed. Not necessarily literate. Smart. That workers are smart. That people who work in personnel offices are smart. That these people are smart enough to understand intuitively that transaction costs are large, even though it is inconceivable that they would have heard of this ivory-tower phrase.

Donohue's conclusion that many of the Illinois results reflect "irrationality and/or inefficiency" ${ }^{\prime \prime}$ follows from his doubtful starting premise that the Illinois experiment took place in a low-transaction-costs setting. If transaction costs were not low, as I have argued, many of Donohue's assessments of the experiment must be amended. In my view, the Illinois experiment was not one in which "obviously inefficient outcomes were readily identified." ${ }^{\prime 6}$ Assume that, from the perspective of a worker and an employer, to forgo $\$ 500$ from the state would be a deadweight loss. ${ }^{67}$ If potential participants were utilitarians, however, they would still regard this loss as worth bearing if they expected the transaction costs of collecting the payment to exceed the expected value of the money they would receive. That many bonuses went uncollected may indicate not irrationality and inefficiency but that workers and employers responded intelligently to the reality of transaction costs. ${ }^{68}$

\section{Legal Rules Often Have Flypaper Effects}

Regardless of what the Coase Theorem itself might predict, Coase the man believes that law may affect the allocation of resources. In The Problem of Social Cost, Coase emphasized that when the state decides to give $B$ an entitlement against $A$, rather than vice versa, $A$ might still conceivably purchase the entitlement from $B$. Nevertheless, Coase has identified two reasons why $A$ would in fact be more likely to end up with the entitlement

64. P. 575. The second sentence of the instruction form for EPG workers read: "[The] purpose is to help you get a job faster." R. Spiegelman \& S. Woodbury, Final Report, supra note 30, app. A3 (HIE Instruction Form).

65. P. 601; see also p. 574 .

66. P. 553, see also p. 553 n.10 In other places, however, Donohue identifies the correct utilitarian calculus, See pp. $572-73$ \& n.64; p. 601 n.120.

67. Because of the possibility of stigma, including self-stigma, even this is debatable.

68. The responses of EPG workers appear to have been particularly shrewd. Workers who declined to participate in the employer-payment program may have anticipated what the experiment later showed: that EPG payments would not result in higher salaries. P. 586. Participation in the employer-payment program did, on the other hand, help some workers land jobs more quickly. EPG workers appear to have been remarkably adept at spotting the unusual situations in which the bonus would help them do this. Some 3.1\% more EPG workers than control-group workers returned to work within the eleven-sweek cutoff period. P. 577. This result is impressive because Notices of Hire were submitted for only $50 \%$ of EPG workers. P. 571 (Table I). Similarly, although bonuses were actually paid to employers of only $2.8 \%$ of EPG workers, EPG workers surpassed the control group by $2.1 \%$ in meeting the job conditions for bonuses. P. 571 (Table I), p. $572 \&$ n.60. 
if the legal system were originally to bestow it upon him. ${ }^{69}$ First, an entitlement will tend to "stick" where it is originally allocated when the costs of transferring the entitlement would exceed the parties' (positive) gains from trading it. ${ }^{70}$ Second, Coase has grudgingly come to embrace the consensus position that the law's conferral of a new entitlement may increase the wealth of the person upon whom it is conferred. If the recipient's income elasticity of demand for the new entitlement were positive, this wealth effect would create the possibility that the recipient would refuse to sell the conferred entitlement even though he would also have refused to buy it if the law had conferred it on someone else. ${ }^{71}$

The Illinois results provide further empirical support for the proposition that legal rules can affect resource allocation. ${ }^{72}$ Both the employerpayment and (especially) the worker-payment experiments succeeded in speeding the reemployment of recipients of unemployment insurance. A true believer in the never-never world of zero transaction costs might have predicted that regardless of the content of government reemployment programs, bribes by those who fund unemployment insurance payments would under all circumstances induce the optimal amount of hiring by employers and of job search by unemployed workers. Dream on. Because of free-rider problems and the like, markets do not in fact generate bribes of this sort.

The Illinois findings prompt intriguing questions about the wealth effects of law. Workers in all three experimental groups ended up earning essentially identical average wages, a result that would surprise many economists. Because the investigators did not gather information on nonwage compensation-in particular on how workers and employers split bonus money-one cannot be sure what the ultimate wealth effects of the various programs were. It is plausible, however, that the nominal recipient of a bonus usually pocketed the entire $\$ 500$. If so, the average worker who received a WPG bonus ended up $\$ 500$ wealthier $^{73}$ than the average

69. Economists increasingly are embracing the notion that a person in whose mind an asset is psychologically vested is likely to ask a higher sum for it than he would offer to acquire an unvested equivalent. See Knetsch, supra note 6 . Coase has yet to address this possibility.

70. See supra note 16 and accompanying text. Donohue agrees. See p. 591.

71. Coase has asserted that land purchasers could avoid risks of future legal changes by means of contractual provisions in land-sale contracts. R. COASE, supra note 1, at 170-73; see also Donohue, p. 550 n.4. This is unconvincing because these provisions would simply shift wealth effects from land buyers to land sellers. Coase has admitted that wealth effects might occur in contexts where legal rights were being recognized for the first time. He states that "apart from such cataclysmic events as the abolition of slavery, these effects will normally be so insignificant that they can safely be neglected." $\mathrm{R}$. CoASE, supra note 1 , at 174 . This example poorly serves Coase's argument because the emancipation of slaves did change previously recognized rights. Although Coase's discussion is somewhat confusing, he concludes by recognizing the possibility of wealth effects. For another critique of Coase's views on this issue, see Schwab, Book Review, supra note 62, at 1178-83.

72. See Ellickson, A Critique of Economic and Sociological Theories of Social Control, $16 \mathrm{~J}$. LEGAL STUD. 67, 91-92 (1987) (citations to other supporting studies) [hereinafter Critique].

73. From this sum should be subtracted the worker's self-stigma and transaction costs of participating. 
worker in both the EPG and the control group. In a sophisticated exploration of this possibility, Donohue discusses variables such as the unobserved productivity attributes of workers and the psychology of entitlement holders. ${ }^{74}$ Despite their incompleteness, the Illinois data add credibility to Schwab's recent experimental finding that contract presumptions can have wealth effects. ${ }^{75}$ The evidence is mounting that most economists have been in the Dark Ages on this topic.

\section{A Rational Person Often Ghooses To Ignore Law}

Law-and-economics scholars tend to be guilty of legal centralism. They are prone to exaggerate the degree to which people actually comprehend and refer to legal rules. ${ }^{76}$ For example, Donohue's discussion of tax considerations implausibly assumes that workers and personnel officers would readily resolve the arcane issue of whether the IRS regards WPG payments to workers as unemployment compensation or as ordinary income. ${ }^{77}$

In another example of legal centralism, The Problem of Social Cost, Coase envisions the state as the exclusive creator of entitlements. ${ }^{78}$ Coase's legal centralism is especially surprising because it is in tension with two of his basic themes: (1) that information (here, legal information) is costly, and (2) implicitly, that governments tend to be less competent than other human institutions. ${ }^{79}$ More consistent with those themes, and also more realistic, is the prediction that rational people will choose to conduct many of their affairs without reference to legal rules.

People often look to informal norms, as opposed to the more complex and hazily distant legal system, for rules by which to govern themselves. The parties to an interaction are especially likely to do this when the stakes are low and when the parties are involved in a continuing relationship. Norms have been shown to trump law in the settlement of, for example, routine contractual disputes, ${ }^{80}$ automobile liability claims, ${ }^{81}$ and

\footnotetext{
74. Pp. 587-90, 602 .

75. See Schwab, supra note 11, at 254-56.

76. Law-and-economics scholars typically analyze issues under the assumption that all actors have perlect knowledge of legal doctrine. See, e.g., W. Landes \& R. Posner, The Economic StrucTURE OF TORT LAw 312 (1987) (admitting their analysis is of law in books, not of law in action); A. Pol.INSKY, stupra note 61, at 48-49 (1983) (discussing administrative-cost aspects of negligence and strict liability rules without mention of relative costs to actors of learning different legal rules); S. Shavel.t, Economic ANalysis of ACCIDENT LAw 7-9 (1987) (implicit assumption that actors know and respond to legal rules). See generally Critique, supra note 72, at 81-90 (on shortcomings of legal centralism).

77. Pp. 596-99. A more realistic question is whether workers would anticipate having more success in hiding WPG bonus payments, as opposed to pass-throughs of EPG bonus payments, from the IRS. In note 107 Donohue discusses the problem of taxpayer noncompliance, but not whether the risk of noncompliance would be identical under the WPG and EPG programs.

78. Coase, supra note 9, at 15.

79. See supra note 62 .

80. See Macaulay, Non-Contractual Relations in Business: A Preliminary Study, 28 Am. Soc. RFv. 55 (1963).

81. See H. Ross, Settled Out of Court 233-42 (1970).
} 
cattle-trespass cases. ${ }^{82}$ When minor disputes like these arise, the parties are highly unlikely to compare the relative advantages of legal and informal entitlements before opting for the latter; instead, they typically decide that it would not be worth the effort to investigate the content of legal entitlements. This approach may be anarchic, but it is not irrational.

The Illinois results tell a mixed story about the influence of law. The Illinois experiment created some unusual, short-lived legal terms that defined the hoops that a worker and an employer together had to jump through before the state would pay one of them a bonus of $\$ 500$. The experimenters strove to keep the legal rules as simple as was feasible under the circumstances and took steps to educate unemployed workers about the rules. These efforts had considerable success in cutting through the fog that separates people from the legal system. Many workers, especially WPG workers, conducted their job searches under the influence of these legal rules.

On the other hand, many more Illinois workers, especially EPG workers, eventually turned their backs on the state's efforts. ${ }^{83}$ Although the reasons for nonparticipation are not entirely clear, the costliness of information is unquestionably part of the story. Some workers may have regarded the instructions for the Illinois programs the same way many consumers of fancy electronic appliances regard the instructions for the least frequently used knobs and buttons: too complicated to be worth mastering. EPG workers, moreover, could anticipate that many employers would balk at the information and decision costs inherent in the EPG program. ${ }^{84}$

In the real world of costly information and imperfect governments, the low usage rates of the worker-payment and employer-payment programs are in no way remarkable. The Illinois results provide further evidence that when the stakes are small (and especially when law at first glimpse looks complicated), people are likely to ignore law.

Scholars should be wary of leaping to the elitist conclusion that people who knowingly ignore legal entitlements are irrational or lacking in cognitive capacity. Although these characterizations may be apt in some instances, a decision to ignore the state is often a smart one. An example involving university life may dramatize the point. Governments currently offer a complex array of financial aids and research grants to university students and professors. These programs are typically more transactionally and informationally complicated than the Illinois bonus program was, but they also carry both higher financial rewards and less stigma. Many

82. See Shasta County, supra note 17. See generally sources cited in Critique, supra note 72, at 84-86.

83. Some $45 \%$ of Illinois workers and $88 \%$ of Illinois employers failed to collect $\$ 500$ bonuses even when all job conditions for payment had been satisfied. Woodbury \& Spiegelman, Bonuses to Workers, supra note 43 , at 525, Table 7.

84. See supra text accompanying notes $30-39$. 
students and professors who could succeed in obtaining aid under these programs nevertheless fail to apply. ${ }^{85}$ Many potential grantees discard descriptive materials on these programs after only a superficial glance. Are these students and professors acting irrationally? Or might many of them be smartly adapting to the realities of costly information and imperfect government?

\section{Concluding Remarks}

Coase has never regarded the market as a powerful river that invariably overwhelms the efforts of lawmakers. This metaphor was Kelman's, not Coase's. The Illinois results can be straightforwardly interpreted as confirming several of Coase's actual beliefs: that transaction costs are large and that people know this fact and respond rationally to it.

Donohue started from the premise that transaction costs were "low" in the Illinois experiment. This led him to conclude that many workers and firms acted irrationally and inefficiently. I believe transactions costs were "large" in the Illinois experiment, or at least larger than Donohue thinks they were. Because transaction costs were not directly observable in this instance, the Illinois results do not definitively support either Donohue's interpretation or my own.

It does not follow, however, that debates over levels of transaction costs are inherently unresolvable. Increasingly, law-and-economics scholars are moving beyond armchair theorizing to empirical work. Case studies that reveal the influence of transaction costs are beginning to accumulate. Among laboratory studies, the most notable experiments are those by Hoffman and Spitzer and by Schwab. ${ }^{86}$ Laboratory settings are highly artificial, however, perhaps more artificial than experimenters tend to realize ${ }^{87}$ Additions to the small corpus of studies on real-world situations are therefore especially valuable. For his contribution, John Donohue deserves congratulation.

The assemblage of these sorts of case studies should lead to the sort of slow and fitful progress that is characteristic of the social sciences. From this jumble of observations an analyst can induce a hypothesis about the

85. See, e.g., State Has Money To Give Away to College Students, United Press Int'l, Aug. 30, 1989 (available on NEXIS, Omni library); There's More Aid Than Some People Think, N.Y. Times, Nov. 14, 1982, § 12, at 13, col. 1 .

86. See sources cited supra notes $11,57$.

87. In a recent article Coursey, Hoffman and Spitzer note that their format "excluded most suurces of transaction costs by bringing the parties together, modelling only two parties to the dispute, paying the subjects for their time, and providing standard form contracts that were perfectly enforced." Coursey, Hoffman \& Spitzer, supra note 57, at 234. This list, long though it is, does not exhaust the artificialities of laboratory settings. Experimenters also tend to provide their subjects, on a platter, pertinent legal and factual information about quality, title, and price that real bargainers must grub for. In addition, as Donohue points out, p. 552 \& n.8, laboratory experimenters encourage their subjects to bargain, whereas in some real-world settings there are norms against arms-length trading. 
magnitude of some variety of transaction costs. That hypothesis can in turn be subjected to field tests and therefore potentially falsified.

Additional variations in the Illinois experimental format, for example, could have helped settle some of the issues that Donohue and I debate. To explore the significance of stigma, the experimenters could have freed a subgroup of WPG workers from the requirement of obtaining employer signatures on the Notice of Hire and Voucher ${ }^{88}$ To get a better sense of the magnitudes of aggregate transaction costs, the experimenters could have increased the bonus amounts in some instances to $\$ 2,000, \$ 5,000$, or whatever, and examined the consequences. ${ }^{89}$

Other simple program variations would have reduced the informational and decisional burdens that employers encountered under the EPG program. ${ }^{90}$ Personnel executives of potential employers could have been instructed about the experiment through mailings or visits. More dramatically, experimenters could have shifted the burden of going forward under the employer-payment program from worker to employer. Under this converse design, the Department would send to the personnel departments of employers the names of thousands of workers currently on the unemployment rolls and would offer to pay an employer a $\$ 500$ bonus each time it hired a listed worker who later satisfied the job conditions. ${ }^{91}$ These sorts of program variations would illuminate the extent to which information costs and decision costs influence workers and employers. Experimental outcomes that refuted the influence of transaction costs would enhance the credibility of rival interpretations, including ones that reject the hypothesis of rational action.

88. To keep the other experimental conditions as constant as possible, Department employees would need to confirm employment through some other process, ideally one involving the same amount of hassle for a worker as the worker would need to go through to secure employer signatures.

89. A potential complication is that increasing a bonus may increase the stigma it carries.

90. For example, the information and decision costs of employers would have been lower if the experimenters had sent employers information packets and lists of workers on the unemployment rolls and if Department employees had relied on computerized payroll data otherwise available to the state to judge when the job conditions for payment of the $\$ 500$ EPG bonuses had been met.

91. To protect workers' privacy interests, when applying for unemployment insurance, workers could have been given the right to take their names out of the experimental sample. 


\title{
Two Notes on the Coase Theorem
}

\author{
George J. Stigler†
}

\section{Testing The Theorem}

Ronald Cloase taught us, what of course we should already have known, that when it is to the benefit of people to reach an agreement, they will seek to reach it. Reaching agreement can be costly in time and other resources, so many potential agreements will not be achieved, but these unachieved agreements will have been inhibited by the smallness of the benefits or the largeness of the costs of agreement.

Does the proposition require proof? One would think not. It is similar to a proposition in international trade: The prices of internationally traded goods in two national markets will differ by no more than the cost of movement of the goods between the markets. Suppose I started to test the proposition and found that a pair of prices differed by more than the costs of movement. I would immediately abandon the test and embark on lucrative arbitrage transactions. Similarly, if I found that Coase's famous grain farmer and cattle rancher were making foolish decisions with respect to the damage to grain from wandering cattle, I would buy the two enterprises and reap a capital gain from an efficient reorganization.

However, that cannot be the entire story; human behavior is not so rigorously deterministic as a multiplication table. There are people who do not care for wealth, more who do not reason well, and vastly more who are incompletely informed. These people will not necessarily achieve optimal agreements, and especially is this true in new circumstances. We do not believe that such people govern important markets: Others who love wealth, reason precisely, and buy information in optimal quantities will call the tune. So one set of empirical studies could be directed to the determination of the efficiency of small markets with special attention to shortrun reactions to altered circumstances ("shocks"). Examples of such situations are (1) the reactions of wages of highly specialized people to large, unpredicted changes in the demand for their services, and (2) the structure of prices in markets for inexpensive antiques.

A second and much more interesting and important set of studies could be directed to the costs of achieving agreements ("transaction costs"). In fact such studies have been undertaken by Demsetz, Williamson, and many others, and much attention has been lavished upon the security

+ Director, Center for the Study of the Economy and the State, University of Chicago. 